\title{
Physico-chemical evaluation of soil resources in different regions of Taza - Taounate, Morocco
}

\author{
Sanae Rezouki ${ }^{1,2, *}$, Aimad Allali ${ }^{1,2}$, Bouchra Louasté ${ }^{3}$, Noureddine Eloutassi ${ }^{2}$ and Mohamed Fadli ${ }^{1}$ \\ ${ }^{1}$ Laboratory of Plant, Animal and Agro-industry Productions, Faculty of Sciences, University of Ibn Tofail, \\ Kenitra, Morocco \\ ${ }^{2}$ Laboratory of Engineering, Molecular Organometalic Materials and Environment, Faculty of Sciences Dhar El \\ Mahraz (FSDM), Sidi Mohamed Ben Abdellah University, Fez-Morocco and Regional Center for the Trades of \\ Education and Training (CRMEF), Fez-Morocco \\ ${ }^{3}$ Laboratory of Biotechnology, Environment, Agri-food and Health, Faculty of Sciences Dhar El Mahraz, Sidi \\ Mohamed Ben Abdellah University, Fez-Morocco
}

\begin{abstract}
The area studied Taza-Taounate is a vast mountain range in north-central Morocco, characterized by a variation in bio-geographical factors that encourage a vibrant and diversified vegetation cover with a remarkable rate of endemism compared to Moroccan flora. Our work involves the physicochemical analysis of soils at seven stations in the study area. Three surface soil samples $(0-15 \mathrm{~cm})$ were collected and analyzed for physical and chemical parameters using standard laboratory techniques at each station.

The results showed the clay fraction's dominance in S2 and S3 and the silt fraction in stations S1, S4, S5, S6, and S7. The studied soils have low levels of organic carbon (0.97\% to 2.29\%), high levels of $\mathrm{CaCO}_{3}$ ( $10.1 \%$ to $24.9 \%$ ), and neutral and slightly alkaline $\mathrm{pH}$ (7.01to 7.81). The most dominant element in all stations is calcium exchangeable, with values ranging from 51.52 to $74.91 \mathrm{cmol}+/ \mathrm{kg}$. The other exchangeable basic cations $\left(\mathrm{Mg}^{2+}, \mathrm{Na}^{+}, \mathrm{K}^{+}\right)$have relatively low levels. CEC values vary between 36.12 and $81.13 \mathrm{cmol}+/ \mathrm{kg}$, indicating that our soil type is heavy to organic.
\end{abstract}

Keywords: Organic matter; pH; Texture; CEC; Exchangeable bases.

\section{Introduction}

Nature is full of resources with virtues beneficial to humans. It is generally known that natural resources play an important role in productive and incomegenerating activities and offer social and economic development ${ }^{1}$. The conservation and development of those resources presuppose a precise knowledge of that heritage.

Soils are one of the earth's natural resources essential for agricultural development and ecological sustainability. They are precious natural mines, even though they are often neglected or poorly managed.

Worldwide, climate plays a determining role in distributing major vegetal formations ${ }^{2,3}$, though other factors can sometimes play a dominant position, such as human intervention, paleo-climatic variations, and edaphic influences ${ }^{4,5}$. The valorization of soil resources is an essential objective for man, as it increases the quantity and quality of arable soils, facilitates environmental management, and improves the productivity of cultivated soils ${ }^{6}$. The physiochemical properties of natural soils

*Corresponding author: Sanae Rezouki

Email address: rezoukisanare@gmai.com

DOI: http://dx.doi.org/10.13171/mjc10902011111537sr develop under natural conditions through biotic and abiotic factors over a long period. These properties influence soil fertility and soil productivity; they determine the water retention capacity, the penetration capacity of roots, the ease of water absorption by plants, and the movement of gases in the soil. Soil physical properties also influence forest tree species' distribution, growth, and forest agricultural biomass ${ }^{7}$.

Some plant nutrients and minerals exist as positively charged ions, or "cations", in the soil. Some of them are most important for plants, affecting plant species' growth and development, including nitrogen, phosphorus, and potassium. Among the most common cations found in soils are hydrogen $\left(\mathrm{H}^{+}\right)$, aluminum $\left(\mathrm{Al}^{3+}\right)$, calcium $\left(\mathrm{Ca}^{2+}\right)$, magnesium $\left(\mathrm{Mg}^{2+}\right)$, and potassium $\left(\mathrm{K}^{+}\right)$. Soil $\mathrm{pH}$, a measure of the active hydrogen ion $\left(\mathrm{H}^{+}\right)$, indicates the acidity or alkalinity of forest soils and is also known as the "soil reaction". The most important soil pH effect is on ionic solubility, which affects microbial and plants growth ${ }^{7}$. 
The Taza-Taounate region constitutes a biogeographical unit that forms an entirely original natural setting. By its great geographical contrasts and diversity of geological features, the region offers a varied range of bioclimates that allow the installation of a rich flora with considerable endemism compared to the Moroccan flora in general. However, this region suffers from local development failure even though it is rich in natural resources, mainly aromatic and medicinal plants. In order to develop aromatic and medicinal plants in the Taza-Taounate region, the soil's physicochemistry is one of the ecological factors that determine plants' distribution in the environment ${ }^{8}$ and influences the yield and biochemical composition of the essential oils of these plants. This influence is mainly due either to the soil's physical characteristics, its texture, or its structure ${ }^{9}$.

To better understand the soil resources of TazaTaounate (Northern Morocco), the physicochemical characteristics of seven representative sites covering the entire plant biodiversity have been evaluated to enable sustainable management of this natural environment.

\section{Methods and Analyses}

\subsection{Study areas}

The study area is located in the Fez-Meknes region, including two administrative provinces, Taza and Taounate (Fig 1 and Table 1). The climate of TazaTaounate region is warm and temperate. The winter is characterized by much more rainfall than in the summer. This location is classified as Csa (warm mild climate with summer dry (Mediterranean) by Köppen and Geiger ${ }^{10,11}$.

The average annual temperature in Taza is $17.9^{\circ} \mathrm{C}$ and $17.0^{\circ} \mathrm{C}$ in Taounate. The rainfall averages 563 $\mathrm{mm}$ per year in Taza and $655 \mathrm{~mm}$ in Taounate Fig. 3 and 4) ${ }^{12}$.

Table 1. Geographic and climatic data for the study regions.

\begin{tabular}{|c|c|c|c|c|}
\hline Stations & Latitudes & Longitudes & Average precipitation & Average \\
\hline S1 : Bouadel & $34^{\circ} 32^{\prime} 24^{\prime \prime} \mathrm{N}$ & $4^{\circ} 30^{\prime} 27.36^{\prime \prime} \mathrm{E}$ & 612 & 16.6 \\
\hline S2: Ain Madyouna & $34^{\circ} 29^{\prime} 54.175^{\prime \prime} \mathrm{N}$ & $4^{\circ} 32^{\prime} 54.74^{\prime \prime} \mathrm{E}$ & 601 & 18.0 \\
\hline S3: Ther Souk & $34^{\circ} 39^{\prime} 7.56^{\prime \prime} \mathrm{N}$ & $4^{\circ} 16^{\prime} 43.032^{\prime \prime} \mathrm{E}$ & 517.2 & 18.1 \\
\hline S4: Ras Lma & $34^{\circ} 847.303^{\prime \prime} \mathrm{N}$ & $4^{\circ} 00^{\prime} 57.701 " \mathrm{E}$ & 456 & 12.1 \\
\hline S5: Ras Elouad & $34^{\circ} 23^{\prime} 20.901 ’ \mathrm{~N}$ & $4^{\circ} 30^{\prime} 0.565^{\prime \prime} \mathrm{E}$ & 543 & 18.9 \\
\hline S6: Chiker & $34^{\circ} 4^{\prime} 10.147^{\prime \prime} \mathrm{N}$ & $4^{\circ} 5^{\prime} 23.063^{\prime \prime} \mathrm{E}$ & 606 & 10.4 \\
\hline S7: Tainaste & $34^{\circ} 31^{\prime} 54.853^{\prime \prime} \mathrm{N}$ & $4^{\circ} 77^{\prime} 38.813^{\prime \prime} \mathrm{E}$ & 521 & 14.1 \\
\hline
\end{tabular}

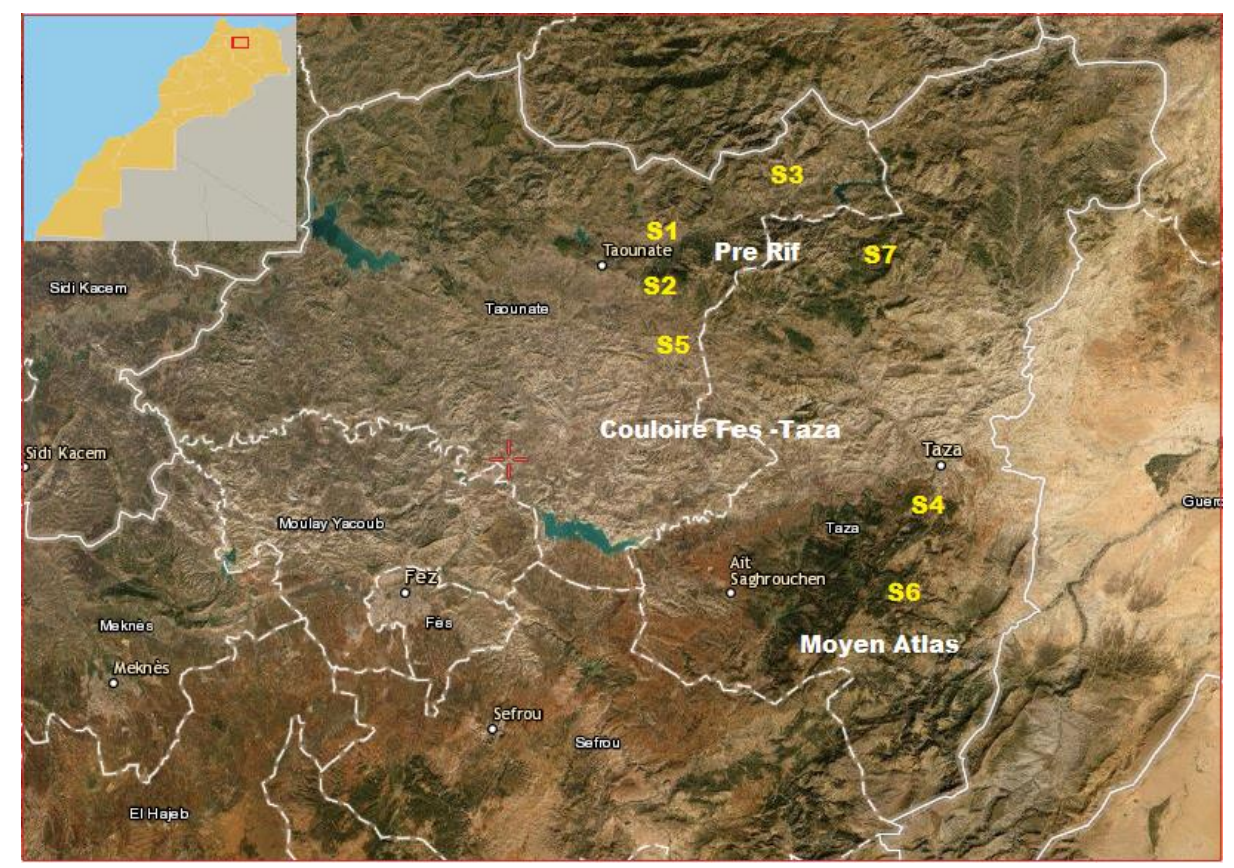

Taza-Taounate area

S1 : Bouadel, S2 : Ain Madouna, S3 : Ther Souk, S4 : Ras Lma, S5 Ras ElOuad, S6 : Chiker (Bab Boudir), S7 : Tainaste.

Figure 1. Geographic location of the study area 


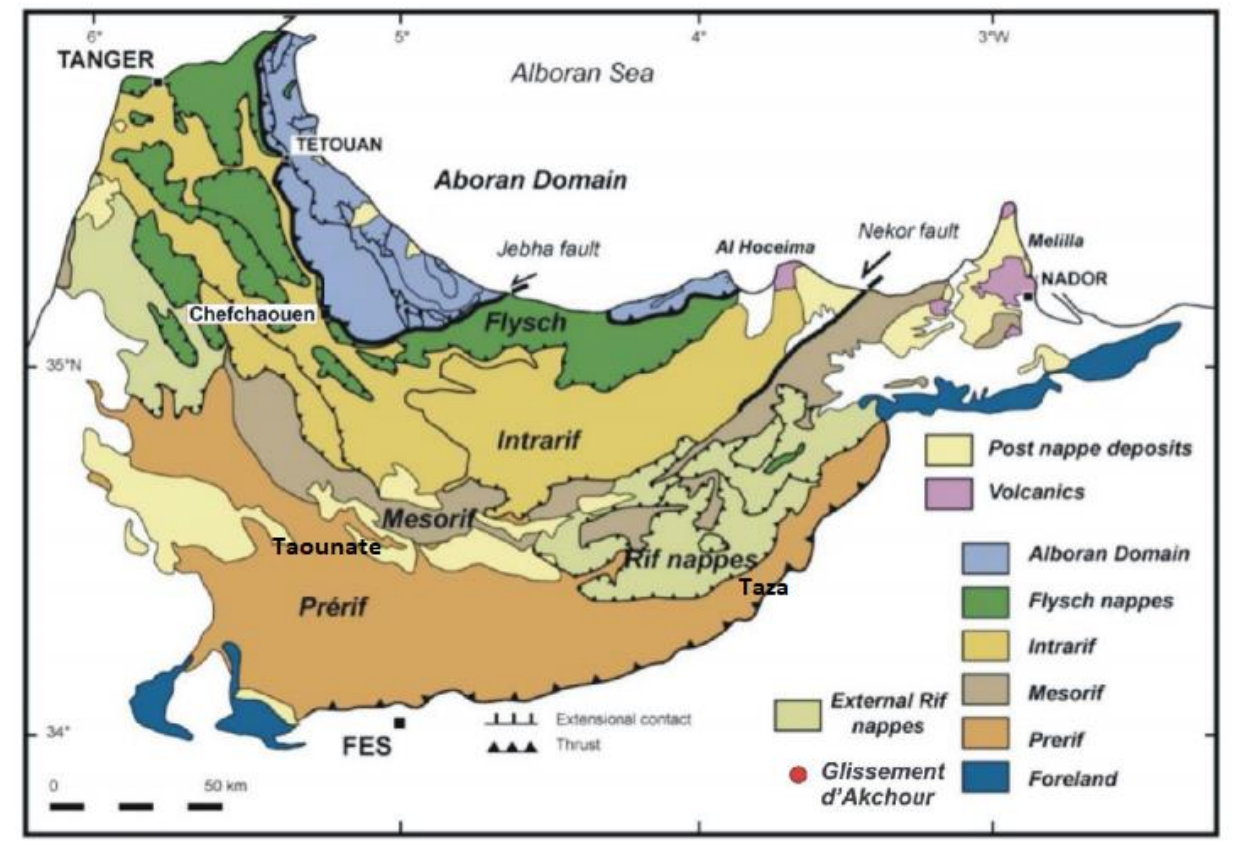

Figure 2. Geological map of the study area ${ }^{14}$

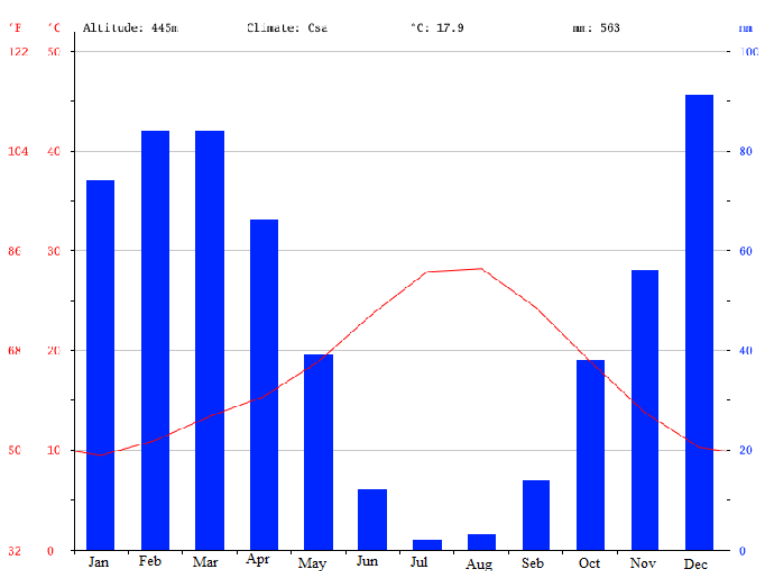

Figure 3. Climate diagram of Taza

\subsubsection{Sampling and Analyses}

Three soil samples were collected from seven different stations/villages for 21 surface soil samples taken at Taza-Taounate. Soil samples were collected using a hand auger. The soil was dug down to $20 \mathrm{~cm}$ deep in a V-shape. This depth represents the soil where most of the roots are located and where nutrient absorption occurs. The field is traversed in a zig-zag pattern by taking sub-samples (composite sample) at random throughout the field area.

Various analyses were carried out at the laboratory level, including air drying, sieving, and soil analysis.

\subsubsection{Particle size distribution}

In the present study, all samples were dried at $40^{\circ} \mathrm{C}$ while grinding, and sieving was done at $2 \mathrm{~mm}$. The destruction of the aggregates was carried out by oxygenated water. A series of screens carried out the separation of the different classes of particles with mesh sizes of $2 \mathrm{~mm}, 1 \mathrm{~mm}, 500 \mu \mathrm{m}, 250 \mu \mathrm{m}$, $125 \mu \mathrm{m}$, and $63 \mu \mathrm{m}$ to recover the very coarse,

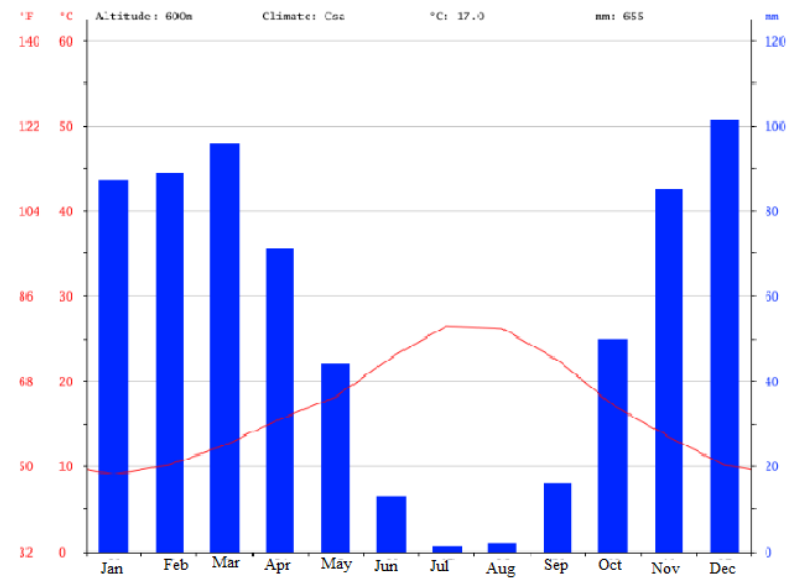

Figure 4. Climate diagram of Taounate

coarse, medium, fine, and very fine soil fractions respectively. The operating procedure is that of ASTM D--422 with some modifications ${ }^{15}$.

\subsubsection{Soil pH, Conductivity, and Moisture}

Soil humidity was calculated by the difference between fresh and dry weight ${ }^{16}$ after drying $1 \mathrm{~g}$ of the soil sample in an oven for 24 hours at $105^{\circ} \mathrm{C}$. The percentage is determined as follows:

$H \%=\frac{P f-P s}{P s} \times 100$

Where $\mathrm{H} \%=$ humidity in the field; Pf = fresh weight of the sample before drying; Ps = dry weight of the sample after drying.

The $\mathrm{pH}\left(\mathrm{pH}-\mathrm{H}_{2} \mathrm{O}\right.$ and $\left.\mathrm{pH}-\mathrm{Kcl}\right)$ (hydrogen potential) was determined by the method of ${ }^{17}$; the conductivity measurement was carried out with a Hanna HI2316 conductivity meter. 


\subsubsection{Soil organic matter}

We determined the soil organic matter using Walkley and Black ${ }^{18}$, which consists of oxidizing the organic fraction of carbon by a mixture of potassium dichromates in an acidic medium. The organic matter rate is estimated by multiplying the percentage of organic carbon by factor 1.724 .

\subsubsection{Carbonate}

We have adopted the calcium carbonate $\left(\mathrm{CaCO}_{3}\right)$ solubilization method by the acid $(\mathrm{HCl})$ attack ${ }^{16}$ under the same temperature and pressure conditions, and then the $\mathrm{CO}_{2}$ volume released was measured using Bernard's calcimeter.

\subsubsection{Exchangeable Cations, Cation exchange capacity}

Exchangeable bases: by saturation with $1 \mathrm{~N}$ ammonium acetate solution adjusted to $\mathrm{pH}=7$. The cation determination was carried out by atomic absorption and flame photometer; cation exchange capacity (CEC): determined by the sodium acetate method.

\subsection{8. available phosphorus}

According to the Olsen 1965 method, available phosphorus was determined, and the Nitrates-N was determined by chromotropic acid.

\subsection{Statistical analysis}

To compare the values of different variables (physicochemical parameters) between study sites, means \pm standard deviations (SD) are calculated based on raw data from the samples taken. The data were subjected to an analysis of unidirectional variance (ANOVA) at the significance level $\mathrm{P} \leq 0.05$ in order to determine the difference between the group's extreme values. Fisher's Least Significant Difference (LSD) test was used to separate significant from non-significant averages at $\alpha=0.05$.

Uni-variate (Correlation tests) and multi-variate (Hierarchical classification) statistical analyses were carried out on these data to determine the different correlations existing between these parameters.

\section{Results}

\subsection{Soil physical characteristics of study sites}

Table 2 shows the results of the physical characteristics of the soils at seven study sites. The particle size analysis shows the clay fraction's dominance in $\mathrm{S} 2$ and $\mathrm{S} 3$ and the silt fraction in stations S1, S4, S5, S6, and S7. Quantitatively, the clay content reaches the maximum values of $48.3 \%$ and $42.9 \%$ in S3 and S2, respectively, while the silt percentage is very high in station $\mathrm{S} 4$ with a value of $41.2 \%$.

Table 2. Soil mechanical composition and textural classes.

\begin{tabular}{|c|c|c|c|c|c|c|}
\hline Parameters & \multirow{2}{*}{ Clay $(\%)$} & \multirow{2}{*}{ Silt $(\%)$} & \multicolumn{3}{|c|}{ Sands (\%) } & \multirow{2}{*}{$\begin{array}{c}\text { Soil } \\
\text { texture }\end{array}$} \\
\hline Stations & & & $F s$ & $M s$ & $C s$ & \\
\hline S1 : Bouadel & $23,1 \pm 0.2^{\mathrm{a}}$ & $63,9 \pm 2.7^{\mathrm{a}}$ & $4,8 \pm 0.17^{a}$ & $7,56 \pm 0.45^{\mathrm{a}}$ & $29,5 \pm 0.66^{\mathrm{a}}$ & loam \\
\hline S2 : Ain Madyouna & $42,8 \pm 1.4^{b}$ & $25,6 \pm 0.6^{b}$ & $19,8 \pm 098^{b}$ & $6,5 \pm 0.61^{b}$ & $5,35 \pm 0.5^{b}$ & clay \\
\hline S3 : Ther Souk & $48,4 \pm 1.9^{c}$ & $22,4 \pm 1^{\mathrm{c}}$ & $2,7 \pm 0.28^{c}$ & $11,36 \pm 0.55^{c}$ & 15,3 & clay \\
\hline S4 : Ras Lma & $23,6 \pm^{a}$ & $41,2 \pm 0.8^{\mathrm{d}}$ & $4 \pm 031^{a}$ & $15,89 \pm 0.38^{d}$ & $15,3 \pm 0.78^{c}$ & Loam \\
\hline S5 : Ras ElOuad & $20,7 \pm 0.7^{\mathrm{d}}$ & $37,4 \pm 1.8^{\mathrm{e}}$ & $12 \pm 0.84^{\mathrm{d}}$ & $13,56 \pm 0.45^{\mathrm{e}}$ & $16,2 \pm 0.78^{c}$ & loam \\
\hline S6 : Chiker (Bab Boudir) & $24 \pm 1^{a}$ & $34,7 \pm 1.2^{\mathrm{f}}$ & $7,46 \pm 0.55^{\mathrm{e}}$ & $12,6 \pm 0.62^{\mathrm{e}}$ & $21,1 \pm 0.9^{d}$ & loam \\
\hline S7 : Tainaste & $19,9 \pm 0.5^{\mathrm{d}}$ & $34,6 \pm 1.5^{f}$ & $7,26 \pm 0.75^{\mathrm{e}}$ & $12,66 \pm 0.65^{\mathrm{e}}$ & $25,3 \pm 0.45^{\mathrm{e}}$ & loam \\
\hline
\end{tabular}

Fs: fine sand, Ms: medium sand, Cs: coarse sand

\subsection{Soil chemical characteristics}

\subsection{1. pH, Moisture and ionic Conductivity}

Soil $\mathrm{pH}$ measurement is used to define its acidity or alkalinity. According to ${ }^{19}$ international standards, our results show that Bouadel's soil is alkaline, whereas other soils are only slightly basic. The soil $\mathrm{pH}$ values found in these different stations ranged from a minimum value of 7.01 in Tainaste, to a maximum value of 7.81 recorded in Bouadel (Table 3).

Humidity is proportional to soil texture; clay soils are very humid while sandy soils are less humid. All study sites are composed of moist soil with a maximum value of $15.9 \%$ at Ther Souk and a minimum value of $11.1 \%$ at Tainaste (Table 3 ).
Conductivity measurement showed that Ras ELOuad soil was more conductive with a $275.89 \mu \mathrm{s} / \mathrm{cm}$ value than the other study sites.

\subsubsection{Organic Matter and Carbonate Content}

There is significant variation in the organic matter levels from station to station. The highest rate is recorded at Ras ELOuad 2.29\% and the lowest at Ras Lma 0.97\% (Table 3).

Table 4 also shows that the soils in our study region are very rich in limestone with $25 \%$ maximum in Tainaste and Bab Boudir, followed by $23 \%$ in Ras Lma, then Ain Madyouna and Bouadel with $18 \%$. 


\subsubsection{Exchangeable bases}

The most dominant element is calcium, representing $60 \%$ to $70 \%$ of the exchangeable cations in all stations. The highest levels were present in Ras ELOuad and Thar Souk. At Ther Souk and Ras ELOuad, the magnesium content is relatively high, while potassium and sodium show low levels at all stations (Table 3).

\subsubsection{Cation exchange capacity}

In generally, CEC values are relatively high, in Ras ELOuad and Ther Souk around $81.13 \mathrm{cmole} / \mathrm{kg}$ and
$80.32 \mathrm{cmole} / \mathrm{kg}$. These values fall to $57.89 \mathrm{cmole} / \mathrm{kg}$, $56.12 \mathrm{cmole} / \mathrm{kg} 38.09 \mathrm{cmole} / \mathrm{kg}$ and $36.12 \mathrm{cmole} / \mathrm{kg}$ in Ain Madyouna, Bouadel, Ras Lma, Tainaste and Bab Boudir (Table 3).

\subsubsection{Nitrates and Assimilable Phosphorus}

Assimilable phosphorus is significant at all stations, with a maximum value recorded at Tainaste and a minimum value recorded at Ras Lma. It is deficient for nitrate compared to the phosphorus value at all stations, with a minority value recorded at Tainaste (Table 3).

Table 3. Physico-chemical parameters of soil resources at different stations.

\begin{tabular}{|c|c|c|c|c|c|c|c|}
\hline $\begin{array}{l}\text { Stations } \\
\text { Settings }\end{array}$ & S1 : Bouadel & $\begin{array}{l}\text { S2 : Ain } \\
\text { Madyouna }\end{array}$ & $\begin{array}{l}\text { S3 : Ther } \\
\text { Souk }\end{array}$ & S4 : Ras Lma & $\begin{array}{l}\text { S5 : Ras } \\
\text { ElOuad }\end{array}$ & $\begin{array}{c}\text { S6 : (Bab } \\
\text { Chiker) }\end{array}$ & $\begin{array}{c}\text { S7 : } \\
\text { Tainaste }\end{array}$ \\
\hline $\mathbf{H}(\%)$ & $12,2 \pm 0,2 \mathrm{a}$ & $14,09 \pm 0,4 \mathrm{~b}$ & $15,9 \pm 0,5 \mathrm{c}$ & $11,2 \pm 0.4 \mathrm{~d}$ & $11,3 \pm 0,3 \mathrm{~d}$ & $12,3 \pm 0,4 \mathrm{a}$ & $11,1 \pm 0,6 \mathrm{~d}$ \\
\hline $\mathrm{EC}(\boldsymbol{\mu} \mathrm{S} / \mathrm{Cm})$ & $176,39 \pm 4,14 \mathrm{a}$ & $153,39 \pm 6,63 \mathrm{~b}$ & $198,5 \pm 5,81 \mathrm{c}$ & $153,46 \pm 5,28 b$ & $275,56 \pm 4,6 \mathrm{~d}$ & $131,55 \pm 2,95 \mathrm{e}$ & $145,87 \pm 4,1 \mathrm{~b}$ \\
\hline pH_H2O & $7,81 \pm 0,04 a$ & $7,13 \pm 0,03 \mathrm{~b}$ & $7,02 \pm 0,03 \mathrm{c}$ & $7,52 \pm 0,04 \mathrm{~d}$ & $7,72 \pm 0,05 \mathrm{e}$ & $7,71 \pm 0,03 \mathrm{e}$ & $7 \pm 0,06 \mathrm{c}$ \\
\hline $\begin{array}{c}\mathrm{pH}-\text { ксl } 1 \mathrm{M} \text { of } \\
\text { soil }\end{array}$ & $6,89 \pm 0,05 \mathrm{a}$ & $7,11 \pm 0,02 \mathrm{~b}$ & $6,26 \pm 0,04 \mathrm{c}$ & $7,17 \pm 0,03 b$ & $11,76 \pm 0,25 \mathrm{e}$ & $7,38 \pm 0,04 \mathrm{e}$ & $6,66 \pm 0,05 f$ \\
\hline $\mathrm{CaCO}_{3}(\%)$ & $17,56 \pm 0,25$ a & $18,67 \pm 0,35 \mathrm{~b}$ & $10,1 \pm 0,4 \mathrm{c}$ & $22,93 \pm 0,45 \mathrm{~d}$ & $11,76 \pm 0,25 \mathrm{e}$ & $24,9 \pm 0,26 \mathrm{f}$ & $24,9 \pm 0,2 \mathrm{f}$ \\
\hline OM (\%) & $1,97 \pm 0,03 \mathrm{a}$ & $1,89 \pm 0,05 \mathrm{~b}$ & $2,03 \pm 0,04 \mathrm{a}$ & $0,96 \pm 0,05 \mathrm{~d}$ & $2,29 \pm 0,05 \mathrm{c}$ & $1,85 \pm 0,05 \mathrm{~b}$ & $1,04 \pm 0,04 \mathrm{~d}$ \\
\hline $\mathrm{Ca}^{2}+$ & $61,6 \pm 0,71 \mathrm{a}$ & $62,3 \pm 0,75 \mathrm{a}$ & $68,6 \pm 1,55 \mathrm{~b}$ & $57,5 \pm 2,42 \mathrm{c}$ & $74,6 \pm 1,71 \mathrm{~d}$ & $56,8 \pm 1,97 \mathrm{c}$ & $51,6 \pm 1,65 \mathrm{e}$ \\
\hline $\mathrm{Mg}^{2}+$ & $1,68 \pm 0,02 \mathrm{a}$ & $1,73 \pm 0,04 \mathrm{a}$ & $11,45 \pm 1,57 \mathrm{~b}$ & $10,59 \pm 1,47 \mathrm{~b}$ & $1,74 \pm 0,05 \mathrm{a}$ & $2,18 \pm 0,22 \mathrm{a}$ & $1,71 \pm 0,06 \mathrm{a}$ \\
\hline $\mathrm{Na}+$ & $0,4 \pm 0,03 \mathrm{a}$ & $0,3 \pm 0,02 \mathrm{a}$ & $13,09 \pm 1,9 \mathrm{~b}$ & $0,29 \pm 0,03 \mathrm{a}$ & $1,27 \pm 0,03 \mathrm{a}$ & $0,2 \pm 0,02 \mathrm{a}$ & $0,19 \pm 0,02 \mathrm{a}$ \\
\hline $\mathbf{K}+$ & $0,18 \pm 0,02 \mathrm{a}$ & $0,19 \pm 0,01 \mathrm{a}$ & $0,51 \pm 0,02 \mathrm{~b}$ & $0,19 \pm 0,02 \mathrm{a}$ & $0,42 \pm 0,03 \mathrm{c}$ & $0,24 \pm 0,03 \mathrm{~d}$ & $0,23 \pm 0,02 \mathrm{da}$ \\
\hline $\operatorname{CEC}(\%)$ & $56 \pm 0,95 \mathrm{a}$ & $57,94 \pm 2,08$ a & $80,44 \pm 1,5 \mathrm{~b}$ & $38,36 \pm 1,52 \mathrm{c}$ & $80,71 \pm 1,54$ a & $36,54 \pm 0,84 \mathrm{c}$ & $37,79 \pm 1,97 \mathrm{c}$ \\
\hline $\mathrm{NO}_{3^{-}}(\mathrm{mg} / \mathrm{kg}$ soil $)$ & $11 \pm 0,95 \mathrm{a}$ & $10,41 \pm 1,57 \mathrm{a}$ & $17,23 \pm 0,75 b$ & $16,01 \pm 1,1 \mathrm{bc}$ & $15,77 \pm 1,63 \mathrm{c}$ & $17,55 \pm 1,33 b$ & $5,97 \pm 0,99 \mathrm{~d}$ \\
\hline $\mathbf{P}_{2} \mathbf{O}_{5}(\mathrm{mg} / \mathrm{kg}$ soil $)$ & $28,63 \pm 0,76 \mathrm{a}$ & $29,07 \pm 0,71 \mathrm{a}$ & $24,72 \pm 1,02 b$ & $22,42 \pm 0,95 \mathrm{c}$ & $23,23 \pm 0,88 \mathrm{bc}$ & $24,53 \pm 1,05 b$ & $30,45 \pm 1,03 \mathrm{~d}$ \\
\hline
\end{tabular}

H: Moisture, pH: Water Potential, EC: Conductivity; OM: Organic Matter, CaCO $\mathrm{C}_{3}$ Total Limestone; CEC: Cation Exchange Capacity; $\mathrm{NO}_{3}:$ Nitrate, $\mathrm{P}_{2} \mathrm{O}_{5}$ : Assimilable Phosphorus.

Table 4. Correlation matrix.

\begin{tabular}{|c|c|c|c|c|c|c|c|c|c|c|c|c|c|}
\hline & $H$ & $C E$ & $p \mathrm{H}_{-} \mathrm{H}_{2} \mathrm{O}$ & $p H \_K c l$ & $\mathrm{CaCO}_{3}$ & $M O$ & $\mathrm{Ca}$ & $M g$ & $\mathrm{Na}$ & K & $C E C$ & $\mathrm{NO}_{3}$ & $\mathrm{P}_{2} \mathrm{O}_{5}$ \\
\hline$H$ & 1,000 & & & & & & & & & & & & \\
\hline$C E$ & 0,002 & 1,000 & & & & & & & & & & & \\
\hline pH_ $\mathrm{H}_{2} \mathrm{O}$ & $0-, 497$ & 0,241 & 1,000 & & & & & & & & & & \\
\hline pH_Kcl & $-0,580$ & 0,011 & 0,688 & 1,000 & & & & & & & & & \\
\hline $\mathrm{CaCO}_{3}$ & $-0,556$ & $-0,816$ & 0,042 & 0,368 & 1,000 & & & & & & & & \\
\hline$M O$ & 0,451 & 0,613 & 0,314 & 0,073 & $-0,732$ & 1,000 & & & & & & & \\
\hline $\mathrm{Ca}$ & 0,355 & 0,902 & 0,201 & $-0,007$ & $-0,929$ & 0,801 & 1,000 & & & & & & \\
\hline$M g$ & 0,410 & $-0,005$ & $-0,292$ & $-0,456$ & $-0,265$ & $-0,262$ & 0,120 & 1,000 & & & & & \\
\hline $\mathrm{Na}$ & 0,802 & 0,275 & $-0,461$ & $-0,764$ & $-0,680$ & 0,315 & 0,451 & 0,673 & 1,000 & & & & \\
\hline K & 0,495 & 0,689 & $-0,224$ & $-0,445$ & $-0,796$ & 0,518 & 0,730 & 0,403 & 0,817 & 1,000 & & & \\
\hline$C E C$ & 0,527 & 0,846 & $-0,066$ & $0-, 316$ & $-0,989$ & 0,765 & ,943 &, 162 &, 629 &, 805 & 1,000 & & \\
\hline $\mathrm{NO}_{3}$ & 0,262 & 0,289 & 0,398 & 0,229 & $-0,354$ & 0,376 & 0,490 & 0,527 & 0,407 & 0,494 & 0,307 & 1,000 & \\
\hline $\mathrm{P}_{2} \mathrm{O}_{5}$ & 0,050 & $-0,389$ & $-0,419$ & $-0,332$ & 0,266 & $-0,133$ &,- 448 &,- 559 &,- 232 &,- 427 &,- 225 &,- 910 & 1,000 \\
\hline
\end{tabular}




\subsection{Correlation between physicochemical properties of soil}

The PCA results concern the matrix of 7 stations and 13 physicochemical parameters. The first two axes alone provide $73 \%$ of the total information. The experience shows that most of the PCA information is usually provided by these two-factor axes F1 and F2. They define the F1 x F2 principal plane that we have chosen for our analysis.

The correlation matrix between the variables shows a significant correlation between $\mathrm{CEC} * \mathrm{CaCO}_{3}$ (-0.989); $\mathrm{P}_{2} \mathrm{O}_{5} * \mathrm{NO}_{3}(-0.910) ; \mathrm{CEC} * \mathrm{MO}(-0.765)$; $\mathrm{MO}^{*} \mathrm{SO}_{3} \quad(-0.732) ; \quad \mathrm{pH}_{\mathrm{H} 2 \mathrm{O}} * \mathrm{pH}_{\mathrm{Kcl}} \quad(0.688)$ and CEC*Na (-0.973). There is also a lower degree of correlation between variables such as $\mathrm{Na} * \mathrm{Mg}$ (0.673); K*MO (0.518); K*CE (0.689); $\mathrm{MO} * \mathrm{CE}$ (0.613) and $\mathrm{NO}_{3} * \mathrm{~K}$ (0.494). These different correlations reflect each parameter's influence on the others and on soil quality (Table 4).

\subsection{Hierarchical classification}

One of the methods of presenting the results, which highlights relatedness (similarities or correlations), is Hierarchical Principal Component Classification (HCPC).

The objective is to represent soils in homogeneous classes so that soils in the same class have similar values in all the variables analyzed. Once these classes have been constructed, it is important to characterize the classes based on the variables or particular individuals ${ }^{20-21}$. The distances between soils are defined from the 14 variables chosen as active in the PCA. The first two axes of the PCA carried out on soils express about $73 \%$ of the information (Fig. 5).

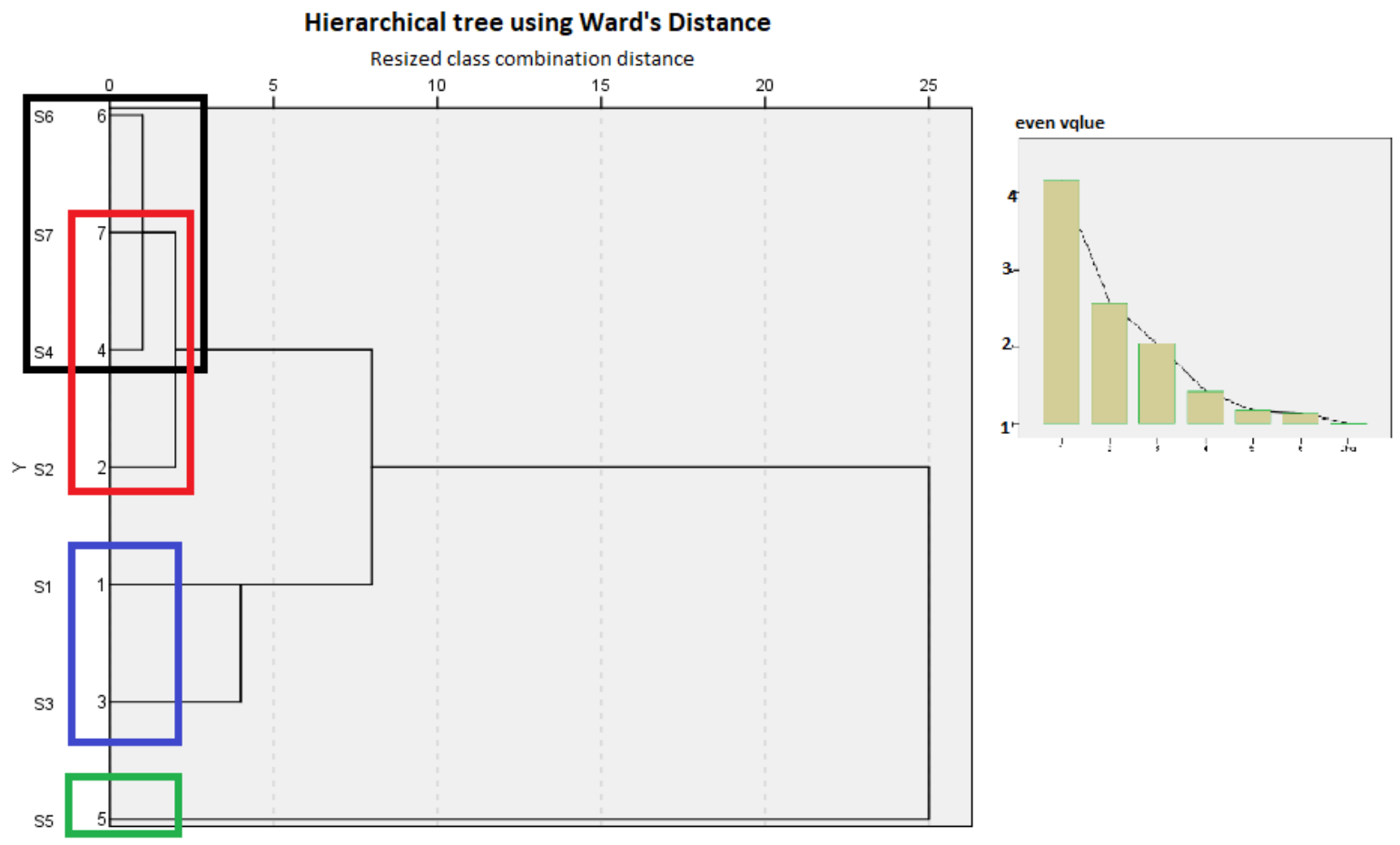

Class 1 framed in black, class 2 in red, class 3 in blue, and class 4 in green.

Figure 5. Hierarchy tree obtained during the HCPC on CPA results

\subsection{Description of classes}

The soil of class 1 belongs to Taza's province; they are characterized by a high $\mathrm{CaCO}_{3}$ content and a low content of clay and exchangeable bases. These are also soils with lower levels of organic matter and CEC. The class 2 soils are characterized by an average value of CEC and EC with very low values in $\mathrm{K}^{+}$and $\mathrm{Na}^{+}$and relatively high in $\mathrm{Ca}^{2+}$ and $\mathrm{Mg}^{2+}$. The class 3 soils are characterized by a varying amount of organic matter and high content of $\mathrm{Ca}^{2+}$. The soil of the class 4 is characteristic because the silt fraction, CEC, EC, $\mathrm{Ca}^{2+}$ and $\mathrm{MO}$ are higher than for all soils. This class is also characterized by soils with very low $\mathrm{CaCO}_{3}$ content.

\section{Discussion}

Many factors influence the considerable variation in soil types found in the Taza-Taounate region. ${ }^{22}$ Generally, it can be said that the nature of the bedrock or source materials, climate, weather, relief, and topography of the terrain are the most critical factors. There are also additional factors; vegetation and human intervention. This work evaluated various soil types to confirm the effects of physicochemical soil characteristics on plant formations and plant distribution in the study areas.

Granulometric analysis of the various soil samples from the study areas indicates that they are rich in clay and silt. Indeed, Gabert ${ }^{23}$ showed that the soils 
come from altering the immediately underlying rocks, present in the form of sandstone marls and especially flysch. These soils' characteristics are incredibly dependent on the bedrock from which they come, its texture, and the chemical and mechanical reactions responsible for its degradation from the depth to the surface. Soil granulometry affects soil's water content and retention capacity with the soil's porosity and permeability characteristics. On the other hand, high clay contents are beneficial for the plants because of its richness in minerals ${ }^{24}$. Its fertility allows the development of many plants with low leaching losses ${ }^{25}$.

In the same way, the clay contents of the surface layer in S1, S4, S5, S6, and S7 are less than those of the other stations. This may be caused by leaching and deposition of clay in the soil. The proportion of hydro-stable aggregates in the soil can be used as a basis for soil fertility and an essential indicator for soil quality assessment, which determines soil structure condition and is vital for the protection of soil organic carbon ${ }^{26}$.

Chemically, the results obtained in our study showed that the $\mathrm{pH}$ is alkaline to neutral at most sites. Soil alkalinity in the soils studied is primarily caused by the nature of the limestone-rich bedrock 27 . Moreover, all cases show that the $\mathrm{pH}\left(\mathrm{H}_{2} \mathrm{O}\right)$ is higher than the $\mathrm{pH} \mathrm{KCl}$, indicating the presence of negatively charged colloids in the soils studied 28. According to ${ }^{29}$, most cultivated plants grow well in neutral or slightly acidic soil, with mean values between 5.5 and 7. The $\mathrm{pH}$ variation depends on seasonal variations in reserve ion numbers on the clay-humus complex, soil water status, temperature, crop presence, or absence of an actively growing crop ${ }^{30}$. In general, this discussion leads us to believe that $\mathrm{pH}$ influences the soil fertility, biological activity, and structural stability.

The soil moisture is another factor influencing the coexistence of fauna and flora in the soil ${ }^{31}$. In all stations, humidity is generally high, with maximum values recorded at Ain Madiouna and Ther Souk in clay soils. These results were explained by Edahbi et al. ${ }^{32}$, who indicate that humidity levels increase as particle diameter decreases.

Conductivity is directly proportional to the soil's salt content. In this study, there is varies from station to station. This variation is mainly due to the salt content of the geological substratum in the area ${ }^{33,34}$. Saline soil is soil with an electrical conductivity greater than $4 \mathrm{ds} / \mathrm{m}$. This study shows that soil salinity varied widely from station to station and directly influenced the distribution of vegetation in the study area.

The study of the relationships between vegetation types and ecosystem functioning was later deepened by the Phyto ecological approach, developed in forest ecology by several authors, as Corcket ${ }^{33}$. They coupled detailed plant community descriptive approaches and quantification of key associated environmental variables such as the mesoclimate, topography, source rock, and soil.

The organic matter contents in the studied soils range from $0.97 \%$ to $2.29 \%$ (Table 4 ). These low values show a deficiency in soil organic matter, so the mineral matter is the main factor in cation exchange ${ }^{27}$.

Base cations, which function as nutrients, also play an essential part in neutralizing acidity and maintaining soil biological activity ${ }^{35}$. In all stations the calcium present in sufficient quantities can meet the plants' needs; the absorbent complex is practically saturated in calcium. Magnesium content is relatively high at Ther Souk, and Ras Lma, potassium, and sodium are low at all stations. Plants do not need sodium; in excess, it becomes harmful.

For the CEC, there are variations between study stations (Table 4). According to ${ }^{27}$ the CEC variation suggests that there is a differentiation in mineralogical proportions of clay. This CEC decrease is explained by the variation in exchangeable cation concentrations from one station to another.

Nitrate $\left(\mathrm{NO}_{3}{ }^{-}\right)$is the assimilable form available to plants; it is activated in soils, non-acidic, and rich in calcium, which is the case for the soils studied. For phosphorus, the assimilable form is represented by the exchangeable ions $\left(\mathrm{PO}_{4}{ }^{3-}\right)$ absorbed by the anionic complex; it is mobilized in a progressive manner ${ }^{35}$. The availability of phosphorus is well related to the nature and condition of the absorbent ${ }^{36}$. In our case, phosphorus is relatively important in the study stations compared to nitrates as it is present in the soil at low values.

\section{Conclusion}

The particle size analysis, the chemical and physicochemical parameters of the studied soils vary from one area to another, affecting plant biodiversity and the installation of aromatic and medicinal plant ecosystems.

Soil chemical characterization showed the presence of a low to neutral basic reaction $(7.02<\mathrm{pH}<7.81)$ with a low to medium content of limestone, assimilable nitrates, available phosphorus, organic matter, exchangeable basic cations, except for calcium, which is present in large quantities, as well as the cation exchange capacity.

After examining the physicochemical data, the soils studied can be considered acceptable ecologically and agriculturally. To protect and sustain these resources, a soil fertility monitoring of agricultural land and a conservation program against the anthropogenic and climatic effects of natural ecosystems is mandatory. In perspective, other physicochemical and biological soil analyses are possible, followed by a study of the distribution of 
aromatic and medicinal plants in the Taza-Taounate region and its relationship with the different types of soil studied.

\section{References}

1- C. Average, M. Desmond, The History of Natural Resource Management in Zimbabwe: A Chronicle of How Sustainable Resource Management Has Remained an Elusive Concept, Journal of sustainable development in Africa, 2017, 9, 102-115.

2- E. Garbolino, P. De Ruffray, H. Brisse, G. Grandjouan, Relations entre plantes et climats en France : étalonnage de 1874 bio-indicateurs, Comptes Rendus Biologies, 2007, 330, 159-170.

3- F.I. Woodward, Climate and Plant Distribution, Cambridge University Press, 1987.

4- J.P.K. Shaumba, J. Lejoly, H.S.M. Nshimba, M.B. Ndjele, K.N. Ngbolua, Physionomical, and pedo- morphological characteristics of vegetation communities of UMA dense forests in the Democratic Republic of the Congo, International Journal of Innovation and Scientific Research, 2017, 30, 119-136.

5- S. Mekideche, L. Brakchi-Ouakour, L. Kadik, Impact des perturbations anthropiques sur la diversité végétale de la subéraie de Chréa, au nord de l'Algérie, Bois \& Forets Des Tropiques, 2018, 337, 53-66.

6- Z. Zhang, W. Zhao, X. Gu, Changes resulting from a land consolidation project (LCP) and its resource environment effects: a case study in Tianmen City of Hubei Province, China. Land Use Policy, 2014, 40, 74-82.

7- N.C. Brady, R.R. Weil, Elements of the nature and properties of soils, Pearson Prentice Hall, 2010.

8- D.H. Wall, R.A. Virginia, Controls on soil biodiversity: insights from extreme environments, Applied Soil Ecology, 1999, 13, 137-150.

9- J. Bethemont, P. Ozenda, Les vegetaux dans la biosphere, Géocarrefour, 1982, 57, 87.

10-R. Geiger, classifications of climates according to W. Köppen, Landolf-Börnstein:Numerical values and functions from physics, chemistry, astronomy, geophysics and technology, 1954, 3, 603-607.

11-W. Köppen, Das geographische system der klimat, Handbuch der klimatologie, 1936, 1-44.

12-Les données climatiques pour les villes du monde entier - Climate-Data.org.

13-Memee. Ministère de l'énergie, des mines, de l'eau et l'environnement : monographie énergétiqueet minière de la région Taza- al Hoceima-Taounate, Rapport, 16p, Rabat, 2011.

14-H. Harmouzi, A. Dekayir, M. Rouai, Analyse géomorphologique et géologique du glissement de terrain d'Akchour (Rif, Maroc), Geo-EcoTrop., 2018, 42, 19-32.
15-American Society for Testing Material, Standard Method for Particle-size analysis of Soil, D. 422-63 (Reapproved 1972) Annual Book of ASTM Standards, Part 19, 1974, 70-80.

16-G. Aubert, Méthode d'analyses des sols, Centre régional de documentation pédagogique (Marseille), 1978.

17-C. Mathieu, P. Françoise, E. Jeanroy, Analyse chimique des sols : Méthodes choisies. Tec \& doc, 2003.

18-A. Walkley, I.A. Black, An examination of the degtjareff method for determining soil organic matter, and a proposed modification of the chromic acid titration method, Soil Science, 1934, 37, 29-38.

19-C. Afnor, Qualité des sols 2 Volumes, 1999, 973.

20-K. Baba, L. Bahi, L. Ouadif, C. Cherradi, Application des méthodes d'analyses statistiques multivariées à la délimitation des anomalies de Sidi Chennane, J. Mater. Environ. Sci., 2014, 5, 1005-1012.

21-R. Monteville, Analyse des caractéristiques techniques et fonctionnelles des élevages de porcs biologiques, 2012.

22-D. Baize, B. Jabiol,Guide pour la description des sols, 2ème édition revue et corrigée, Editions INRA, Paris, 2011.

23-P. Gabert, G. Maurer, Les montagnes du Rif marocain. Etude géomorphologique, Méditerranée, 1970, 1, 89-91.

24-A. Qlihaa, S. Dhimni, F. Melrhaka, N. Hajjaji, A. Srhiri, Caractérisation physico-chimique d'une argile Marocaine [Physico-chemical characterization of a morrocan clay], J. Mater. Environ. Sci., 2016, 7, 1741-1750.

25-G.B. Tesfahunegn, L. Tamene, P.L.G. Vlek, Assessing Soil Properties and Landforms in the Mai-Negus Catchment, Northern Ethiopia, Pedosphere, 2016, 26, 745-759.

26-T. Lan, S.W. Guo, J.W. Han, Y.L. Yang, K. Zhang, Q. Zhang, W. Yang, P.F. Li, Evaluation of physical properties of typical urban green space soils in Binhai Area, Tianjin, China, Urban Forestry \& Urban Greening, 2019, 44, 126430.

27-D. Touhtouh, Y. Moujahid, E.M.E. Faleh, R.E. Halimi, Caractérisations physicochimiques de trios typesde sols du Sais, Maroc (Physicochemical characterizations of three types of soils of Sais, Morocco, J. Mater. Environ. Sci., 2014, 5 .

28-C. Mulaji, P. Disa-Disa, I. Kibal, M. Culot, Diagnostic de l'état agropédologique des sols acides de la province de Kinshasa en république démocratique du Congo (RDC), Comptes Rendus Chimie, 2016, 19, 820-826.

29-J.R. Landon, Booker tropical soil manual: a handbook for soil survey and agricultural land evaluation in the tropics and subtropics, New York; Thame, Oxon, England, 1991.

30-J.P. Thorez, B. Lapouge-Déjean, Le guide du jardin bio: Potager, verger, ornement, édition 
revue et augmentée, Terre Vivante Editions, 2009.

31-E. Lucot, P.M. Badot, S. Bruckert, Influence de l'humidité du sol et de la distribution des racines sur le potentiel hydrique du xylème dans des peuplements de chêne (Quercus sp) de basse altitude, Ann For Sci., 1995, 52, 173-182.

32-M. Edahbi, M. Khaddor, F. Salmoun, Caractérisation des sols du Nord du Maroc (Bassin Loukkos) (Characterization of the soils in North Morocco (Loukkos area)), Mater. Environ. Sci., 2014, 5, 2133-2138.

33-E. Corcket, Biodiversité et interactions biotiques dans les communautés végétales de l'Anthropocène : Mémoire d'abilitation à diriger des recherches, Université de Bordeaux, France, 2015.

34-S.M. Mahamat, M.D. Diallo, O. Ndiaye, Influence des caractéristiques physico-chimiques des sols sur la flore et la végétation ligneuse de trois stations du tracé de la grande muraille verte du Tchad, Journal of Applied Biosciences, 2015, 95, 8937-8949.

35-P. Duchauffour, Introduction à la science du sol Sol, végétation, environnement, 6e édition, Paris, 2001.

36-P. Duchauffour, Abrege de pedologie : Sol, végétation, environnement, 5ème édition, France, 1997. 